\title{
Spiritual Values: A Question of Existence in William Faulkner's the Sound and the Fury and Absalom, Absalom!
}

\author{
B. Arokia Lawrence Vijay
}

\begin{abstract}
Values are the necessary code for human conduct for harmonious life of integrity. Human beings are rational; they have reason for each and every action. Their actions bring out their beliefs, attitudes and custom. William Faulkner in his novels The Sound and the Fury and Absalom, Absalom! delivers perfect medium of the values in spirituality and absence in it. This research work focuses on the absence of spiritual values which lead to confusion and disorientation in the lives of many characters. All the characters discussed in the works of William Faulkner gives a perfect medium of trouble not only to self but also to others just because of the least consideration that is given to the values based on spirituality.
\end{abstract}

Key Words: values, spirituality, confusion, disorientation

\section{INTRODUCTION}

William Faulkner can be compared with Dickens, for exposing the trivialities of everyday life, the little worries, the little pleasure, the little hardship, the little tragedies and ever flowing sympathy. But Faulkner does not allow a ray of humor to radiate his novels. He has charted the inner crisis of the modern man. The problem of meaninglessness is so pervasive that it threatens to corrode every sphere of human life.

The idea of perfection in man makes him spiritual. In the highest spiritual attainment, there is a purest existence, purest conscience, knowledge and the purest peace of bliss. Morality and spiritual go together. 'Telling Truth' is a moral principal; being spontaneously truthful is a spiritual virtue. The highest spiritual value of state is within man himself spiritual progress brings wisdom, contentment, peace and joy. Man has the principal of the spiritual in him and the basic principles of spiritual values are love, compassion, detachment, faith in God, forgiveness Renunciation, sense of order, sense of priority, sympathy etc. These values serve as a basic to have spiritual values in an individual.

Spiritual Values: A question of reality

William Faulkner's use of religious motifs in his novel has merited his works. Religious themes in terms of character development affect these spiritual concerns. John

Revised Manuscript Received on July 08, 2019.

B. Arokia Lawrence Vijay, Assistant Professor of English(SRG, Kumaraguru College of Technology, Coimbatore, Email arokialawrencevijay.b.sci@kct.ac.in.
W. Hunt (1972) says, "It is no longer necessary to argue that Faulkner's works have a religious center; rather the task in this area of Faulkner analysis has to make a case for the kind of religiousness involved and to determine the degree of theological integrity in his fiction as a whole." (168).

The novel The Sound and Fury is of this kind, primarily because of the ultimate spiritual salvation of Dilsey. She is considered as heroine of the novel and her salvation counter points the damnation of those around her. Most of the characters in this novel are found without hope except Dilsey; whose spiritual situation is only an occasion for pity. The redemption of Dilsey's soul parallels her "unburdening" of the Compson misery.

Caroline Compson stands as an opposite figure to Dilsey. When both these characters are compared a complete picture of the secular and spiritual ramifications of Christ's rising from the dead.

Mrs. Compson and her servant supposedly believed in Christianity. Mrs. Compson is living under the shadow of an unforgiving deity, one whose teachings are in firm opposition those that are damned, but their misfortunes are dealing with other problems. Mrs. Compson's damnation comes from the specific failure and her conception towards it has a profound meaning in the negative aspect.

Mrs. Compson firmly believes that God is punishing her in the form of Benjy and it is shown in several scenes in the novel. Mrs. Compsons belief that her youngest child is being "a judgment on me" shows that she thinks that she has a curse from God. This in addition shows her egocentricity and insensitivity to Benjy's condition. This leads to the observation that she thinks her God is so merciless as to wreck her son's life simply to punish her for some unspecified misdeed. This view of Caroline Compson hardly matches with Christianity for forgiving sense. In another instance she wants to obey Caddy's command to lie down in the stairs because she is sick. But it is Mrs. Compson to make a nil - advised attempt to force Benjy to obey her.

Mrs. Compson's attitudes and action suggests that she might be trying to get back the curse by not thinking of her child's welfare. It also displays the utter lack of the charity which Christ showed by giving his life on the cross for the people. She also thinks that God's wrath extends itself into her other children.

What have I done to have been given children like these Benjamin 
was punishment enough and now for her to have no more regard for me her own mother I've suffered for her dreamed and planned and sacrificed I went down into the valley yet never since she opened her eyes has she given me one unselfish thought at times I look at her I wonder if she can be my child except Jason he has never given me one moment's sorrow since I first held him in my arms I knew then that he was to be my joy and my salvation I thought that Benjamin was punishment enough for any sins I have committed I thought he was my punishment for putting aside my pride and marrying a man who held himself above me I dont complain I loved him above all of them because of it because my duty.(152 The Sound and Fury)

In Mrs. Compsons application of the word of God, Mrs. Compson shows only destructiveness that religious belief can cause for those who do not understand it. Mrs. Compson inner part represents selfishness. This stands an evidence that Mrs. Compson does not stand in Christianity and also shows that she does not believe in Christ, who gave his life for her and she cannot follow his examples and give of herself to her family. The real acceptance of oneself comes only when they are accepted by God as God loves every individual in spite of all negatives and disappointments that is given to the God. It is the fact that Mrs. Compson was not able to accept the resurrected Christ. Her failure in this causes her to view all her misfortunes in light of the wrathful God. Christ gave life for everyone but for Mrs Compson, it is not so. She cannot give anything to those around her, not even to her retarded son and she continuously increases the misery of her family.

Though Dilsey and Mrs. Compson, believe in God, the white woman see him as judging her with a handicapped son, Dilsey sees the same person as soul of at least equal importance to her own. To prove this Thomas Kukes asks a question as "why should she take him to the Easter service with her?" Both these women stand as a belief and disbelief in God. This disbelief of Mrs. Compson proves the status of her in spiritual values.

Jason, the most evil person in the novel also represents a kind of Mrs. Compson in many ways. Jason is quite success in his life is due to the fact that he feds no love for any one, normally people would be proud of their ancestry but Jason rejects all blood kin or connection with them. From his section, we see, he never speaks any kind word to any person but he follows Christianity. The word of Christ is to give kindness and peace to others. Jason delights in the acts of perversity. Jason relishes burning two passes which was of free cost for a show. This act is simply to torture a fourteen year old Negro boy which is a total objection and rejection of Christianity. This act of sadism shows Jason is a devil who is against God. Jason's concern for self and all his attitudes and actions towards it states non-humanism. The people who suffer because of Jason is not only Miss. Quentin but also his mother the only one who Mrs. Compson loved. He also represents another part of Mrs. Compson who never considered about religion and spirituality.

Absalom, Absalom! is quite different when compared with The Sound and the Fury with respect to the spiritual values.
In the second and the fury character are analyzed with respect to the values but in Absalom, Absalom! the characters forms a part and they do bear the role of biblical heroes. Henry and Bon exact the parody of the story of Cain and Abel with the white brother slaying the black. In this the murderer was domed for ever to bear the mark of his sin in the form of a black skin.

Absalom ,Absalom! According to the Bible, was the phrase uttered by King David on discovering that one of his sons had murdered the other and the name of the murderer is Absalom. He also murdered his brother for more or less the same reason. Regarding the title and the action of the sons has a greater significance.

This mythological reference in Absalom, Absolam! comes as a part to the novel in order to portray the reality of the world. Not only the particular incident in this novel has a great impact but also Stupen has the same. Stupen is to be compared with Jason in the sound and the fury because he too saves for the self alone. Stupen is likes King David who was concerned with founding a dynasty.

Murder is condemned by every one as a crime, sin and inhuman act. According to the words of Christ it is the responsible of every individual to love each other. He also asks his followers to love the neighbors as they love themselves. But if we have a deep look in Faulkner's novel it is not so.

\section{Conclusion}

As an individual according to Christ everyone should love others, but to Mrs. Compson she not even cared for her own handicapped child and she is very much concerned for herself alone. Jason too is a successful person not in spiritual means rather in the wealth. He too has more attraction towards money and to place himself in a better position in the society. In Absalom, Absolom! Stupen also resembles Jason who solely wants to establish dynasty so commits bigamy and the act of his son who killed the other also states that the spiritual values have not been correctly endured in the characters mentioned. All the character mentioned above leads a typical life; though they follow Christianity they never followed the words of Christ which collapse the whole spiritual values.

Faulkner's work highlights the kinder social problem of human being as basis and an incessant search for a meaningfulness of life. Social criticism in Faulkner is implicit and his fictional voice is the voice of human despair. In fact, Faulkner has used fiction as a platform for his social appeals. In all novels, he has rendered a bitter commentary on the decaying values and ethics of a degenerating civilization.

\section{REFERENCE}

1. William (1990), "The Sound and the Fury", New York: Vintage Book.

2. Faulkner William (1990), "Absalom, Absalom!", New York: Vintage International. 
3. Abadie Ann J, and Evans Harrington(1977), The South and Faulkner's Yoknapatawpha: The Actual and the Apocryphal. Jackson: U P of Mississippi.

4. Jacqueline Scott, Judith Treas, and Martin Richards (2004), "Parenting Practices. The Blackwell Companion to the Sociology of Families" Malden, MA: Blackwell Publishing.

5. Brooks, Cleanth(1963). "William Faulkner. The Yoknanpatawha country". New Haven: Yale

6. Gail, M. Morrison (2008), "The Composition of The Sound and the Fury.”, Infobase Publishing New York

7. Howe Irving (1962), “William Faulkner: A Critical Study", Vintage Books, New York.

8. Miller Douglas T (1963), "Faulkner and the Civil War: Myth and Reality," American Quarterly 15.2.

9. Miner, Ward L(1959), “The World of William Faulkner”, Pageant Book Co., New York.

\section{AUTHORS PROFILE}

B. Arokia Lawrence Vijay, Assistant Professor of English(SRG, Kumaraguru College of Technology, Coimbatore, Email arokialawrencevijay.b.sci@kct.ac.in. 